\title{
TWO NEW SMALL FLOWERED CYRTOCHILUM SPECIES (ORCHIDACEAE: ONCIDIINAE) FROM VENEZUELA
}

\author{
Gilberto Morillo ${ }^{1} \&$ Stig Dalström ${ }^{2,3}$ \\ ${ }^{1}$ Departamento de Botánica, Facultad de Ciencias Forestales y Ambientales, Universidad de Los Andes, \\ Mérida 5101 A, Venezuela \\ 22304 Ringling Boulevard, unit 119, Sarasota FL 34237, U.S.A. \\ Research Associate: Lankester Botanical Garden, University of Costa Rica, Cartago, Costa Rica, \\ and National Biodiversity Centre, Serbithang, Bhutan \\ ${ }^{3}$ Corresponding author: stigdalstrom@juno.com
}

Abstract. During ongoing research on the genus Cyrtochilum Kunth in the Venezuelan Andes, two new species have been found, which are described, illustrated and compared with similar species here.

KeY words: Cyrtochilum, new species, Oncidiinae, Orchidaceae, taxonomy, Venezuela

The number of new orchid species that are being discovered and scientifically described every year is impressive. Some of these are the result of explorations into previously unknown habitats of isolated regions. Often enough though, new species are found in herbaria where they have been hiding under a misapplied name or simply as an undetermined species, sometimes for a century or more. Two such "new" species are described here.

\section{TAXONOMIC TREATMENT}

\section{Cyrtochilum dunstervilleorum G.Morillo \&} Dalström, sp. nov.

TYPE: Venezuela. Táchira, headwaters of Río Quinimari, on felled tree in rainforest clearing on trail to Alto de Tierra Negra, at ca $2500 \mathrm{~m}$, March 1968, G. C. K. Dusterville 1064 (holotype of flowers in alcohol, SEL; dried specimen unknown but illustration at K). Fig. 1.

Cyrtochilum dunstervilleorum is similar to C. megalophium (Lindl.) Kraenzl., but differs in having larger flowers spotted and marked with dark brown, versus uniformly light yellow flowers for $C$. megalophium. The lip of C. dunstervilleorum is rather uniformly cordate versus a distinctly trilobate lip for $C$. megalophium, which also has a much simpler callus.

Epiphytic herb. Pseudobulbs more or less caespitose to repent on a bracteate woody rhizome, ovoid and slightly ancipitous, bifoliate, to $8 \times 4 \mathrm{~cm}$, surrounded basally by up to 8 distichous, foliaceous sheaths. Leaves subpetiolate, conduplicate, fairly rigid with a midvein that is distinctly sulcate above and carinate below, elliptic to obovate, narrowly attenuate obtuse, to $24 \times 4 \mathrm{~cm}$. Inflorescence axillary from the uppermost sheath, erect, to at least $60 \mathrm{~cm}$ long panicle with strongly fractiflex side-branches and 3- to 4-flowered fractiflex branchlets. Bracts appressed and scale like (dimensions unknown). Pedicel with ovary 16-22 mm long. Flower slightly campanulate; dorsal sepal light brown, heavily overlaid with dark brown markings, unguiculate, basally sulcate, lamina broadly elliptic, obtuse, slightly apiculate, 9-11 $\times 4 \mathrm{~mm}$; lateral sepals similar in color, spathulate, basally slightly sulcate, lamina elliptic and slightly oblique, obtuse to acute, $12-13 \times 4 \mathrm{~mm}$; petals similar in color, slightly spathulate, lamina weakly oblique, obtuse to acute, 9.0-10.0 $\times 3.5 \mathrm{~mm}$; lip bright yellow with some dark spots basally, rigidly attached to the base and gradually curved away from the column, cordate to truncate, laminate, obtuse, slightly undulate and microscopically papillate, with a weakly involute apex, 8.0-9.0 $\times 5.5 \mathrm{~mm}$; callus bright yellow, of two erect, fleshy, parallel longitudinal keels emerging at the base and abruptly truncate near the middle of the lamina, with multiple, spreading variably sized denticles in front; column light brown with large dark brown marks on the basal part, then velvety 


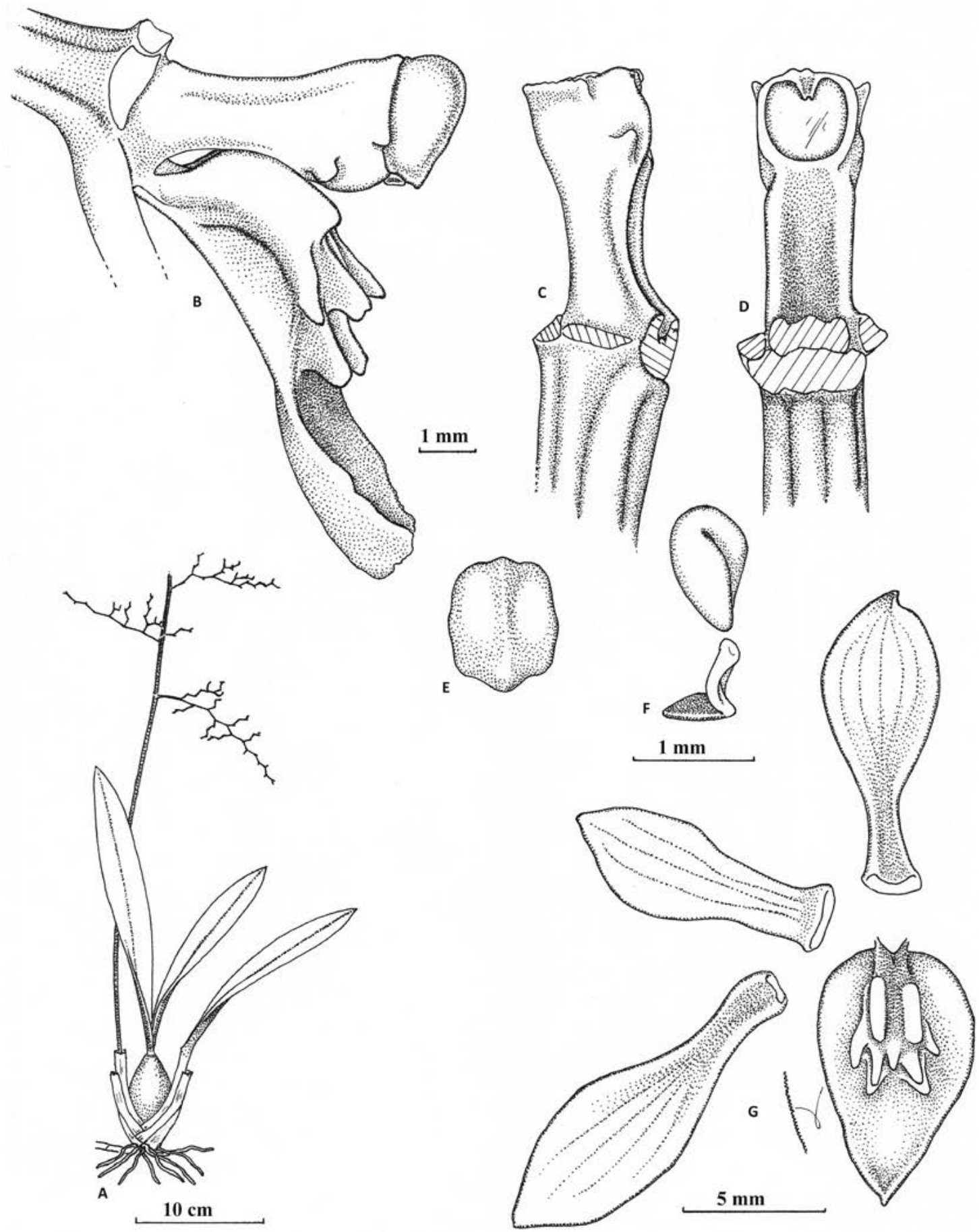

FiguRE 1. Cyrtochilum dunstervilleorum A - Plant habit based on Dunsterville's drawing at Kew. B - Column-lip, lateral view. C - Column lateral view. D - Column ventral view. E - Anther cap, dorsal view. F. Pollinarium with one pollinium. G - Dissected flower. Based on G. C. K. Dunsterville 1064 (SEL). Flower details drawn from holotype by Stig Dalström. 
dark brown, straight, clavate, ventrally canaliculate (or sulcate), with a small, blunt, thumb-like wing on each side of the stigma, apically truncate with a pair of lateral, short and projecting angles, $c a .6$ $\mathrm{mm}$ long; anther cap brown with maroon marks, campanulate and weakly rostrate; pollinarium of two pyriform, folded pollinia on a laminate, $c a .0 .5$ $\mathrm{mm}$ long stipe, on an ovoid, pulvinate, ca $0.5 \mathrm{~mm}$ long viscidium.

Additional SPECimens SEen: A plant of unknown origin on a color transparency ( $G$. Escobar 147, Dalström photo archives) presumably from Colombia. Collections have also been made by $\mathrm{C}$. Fernández et al., near Andrés Bello in Táchira at $2500 \mathrm{~m}$, but the whereabouts of any preserved specimens is unknown (color photo in "Orquídeas nativas del Táchira, by César Fernández; C. Fernández 450).

Eтymology: Named in honor of Ellinor and Galfrid Clement Keyworth 'Stalky' Dunsterville, for their immense contribution to the knowledge of Venezuelan orchids.

Cyrtochilum dunstervilleorum is only known from the upper elevation Andean region in western Venezuela, and most likely eastern Colombia ( $G$. Escobar 147).

Cyrtochilum fernandezii G.Morillo \& Dalström, $s p$. nov.

TYPE: Venezuela. Táchira: El Portachuelo, 3080 m, N08 10,817, W071 54,298. Jan.-Feb. 2010, C. Fernández s.n. (holotype, MER). Fig. 2.

Cyrtochilum fernandezii appears most closely related to C. ramosissimum (Lindl.) Dalström and C. densiflorum (Lindl.) Kraenzl. It differs from the former by the smaller flowers with forward projecting petals and a finely pubescent apical lip callus, and from the latter species by slightly larger and differently colored flowers with a finely pubescent and more elaborate callus on the lip. Cyrtochilum fernandezii is also morphologically similar to $C$. leucopterum (Rchb.f.) Dalström, but differs in having a lip callus that is glabrous near the base and finely pubescent apically, and through a club-shaped column without distinct lateral lobes or ridges, which makes it narrower at the base than at the apex, versus a callus that is pubescent throughout and a column that has broad lateral-ventral column lobes for $C$. leucopterum.

Epiphytic herb. Pseudobulbs caespitose to slightly creeping on a bracteate rhizome, ovoid, ca $7 \times 3 \mathrm{~cm}$, surrounded basally by several distichous, foliaceous sheaths, unifoliate or bifoliate. Leaves subpetiolate, conduplicate, elliptic, obtuse, apiculate, ca 28.0$38.0 \times 2.0-2.5 \mathrm{~cm}$. Inflorescence axillary from the uppermost sheaths, erect to arching, weakly flexuous multiflowered panicle (cut off on type), with spreading almost straight to flexuous 3-7 flowered side branches. Bracts appressed, scale-like 5-15 mm long. Pedicel with ovary ca. 10-15 mm long. Flower pale yellowish to whitish with purple to brown markings basally on all segments; dorsal sepal spathulate, lamina elliptic, obtuse, apiculate, ca $10 \times 4 \mathrm{~mm}$; lateral sepals elongate sub-spathulate, lamina obovate, rounded obtuse and broadly apiculate, $c a .18 .0-20.0 \times 3.5-4.0 \mathrm{~mm}$; petals broadly truncate, linear to slightly obovate and slightly oblique, obtuse, forward projecting, $c a .8 .0 \times 3.5 \mathrm{~mm}$; lip fused rigidly to the base of the column, then forward projecting basally and parallel with the column, then abruptly recurved near the middle, cordate, weakly trilobate with erect and concave lateral lobes and a broadly obtuse, apically canaliculate front lobe, ca. 8-9 $\times$ 4-5 mm; callus of two fleshy longitudinal, glabrous, erect, rounded keels, ending in a digitate denticle, with a finely pubescent fleshy intermediate ridge, ending in multiple and variable, finely pubescent spreading denticles; column straight, stout and clavate, sulcate ventrally with a low median ridge, truncate, with a minute lateral denticle on each side of the stigmatic surface, ca $4 \mathrm{~mm}$ long; anther cap globular; pollinarium of two folded pyriform pollinia on a $c a$. $0.5 \mathrm{~mm}$ long linear stipe, on an equally long, ovoid, pulvinate viscidium.

Additional specimens seen: Venezuela. Merida, Km. 52 from La Victoria to La Grita, just below the top of Páramo la Negra. On large Podocarpus tree by roadside, in a fairly isolated position, elevation close to $3300 \mathrm{~m}(10,000 \mathrm{ft})$, June 1962, G. C. K. Dunsterville 706 (dried specimen unknown, illustration and flowers at $\mathrm{K})$. 


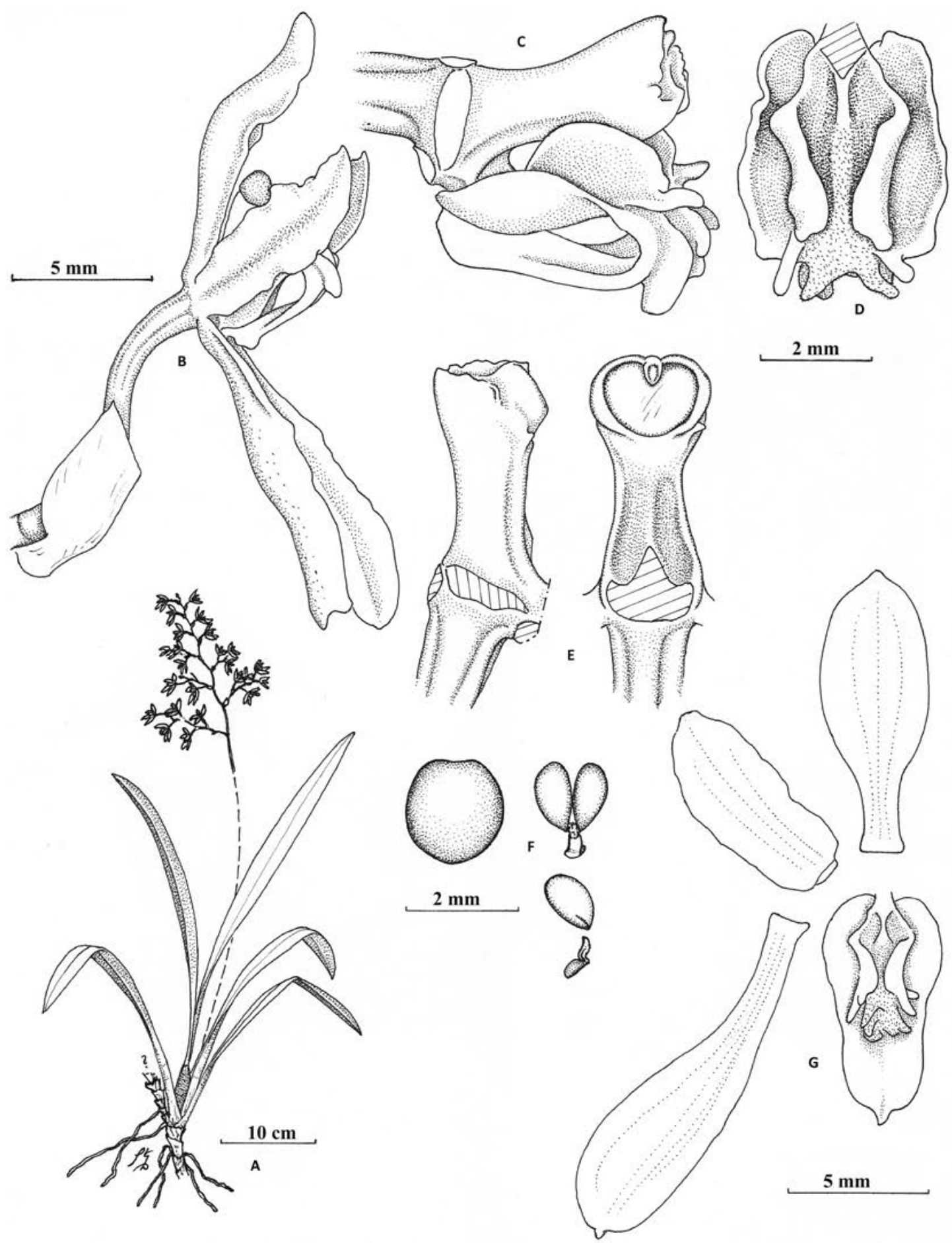

FIgURE 2. Cyrtochilum fernandezii A - Plant habit. B - Flower, lateral view. C - Column and lip, lateral view. D - Lip dorsal view. E - Column lateral and ventral views. F - Anther cap and pollinarium. G - Dissected flower. Based on holotype, Fernández s.n. (MER). Drawn by Stig Dalström. 
Etymology: Named in honor of César Fernández, who has contributed substantially to the knowledge ACKNOwLEDGEMENT. The authors thank Wesley Higgins of the orchid flora in his home state of Táchira, for reviewing and commenting on the manuscript. Venezuela. 